\title{
The Pedagogical Impact of Discourse Markers in the Lecture Genre: EFL Learners' Writings in Focus
}

\author{
Afsaneh Rahimi Tehrani \\ English Department, University of Isfahan, Iran \\ Email: afsaneh_rahimi85@yahoo.com \\ Hossein Vahid Dastjerdi \\ English Department, University of Isfahan, Isfahan, Iran \\ Email: h_vahid@yahoo.com
}

\begin{abstract}
The lecture in its many forms is the most commonly used method for transferring information. The present study investigates the effects of discourse markers in lectures on students' compositions, i.e., whether the use of discourse markers in lectures has positive effect on producing more cohesive texts. 20 male advanced level learners, aged 25 to 40, were chosen from one of the language institutes in Isfahan. The participants were divided into two groups. Two texts for giving lectures were chosen related to "Science and Technology", as it was the title of one of the units in the students' book. In order to compare the comprehension of the participants from the text, discourse markers were used in the lecture of group 1 (G1) and in the other lecture for group 2 (G2) no discourse marker was used. Finally, the cohesive devices used in each composition were identified and counted by the researcher. Frequency, mean and standard deviation of the cohesive devices in each category were computed using SPSS. The results indicate that G1 used more cohesive devices in their writings and therefore produced more coherent texts, i.e. the use of discourse markers facilitated their comprehension and had positive effect on producing more cohesive compositions.
\end{abstract}

Index Terms-lecture genre, discourse markers, cohesive devices, composition, coherent text

\section{INTRODUCTION}

Communication is viewed as a process of transferring thoughts from one person's mind to another's. The benefits of interaction, for improving comprehension and enhancing communicative competence on behalf of students, have been the focus of many studies from a psycholinguistic perspective (e.g., Gass (1997), Gass and Madden (1985) In: S. Gass and C. Madden, Editors, Input in second language acquisition, Newbury House Publishers, Cambridge, MA (1985). Gass and Madden (1985), Gass and Varonis, (1994), Long, (1981) and Pica et al., (1987) and from a socio-cultural perspective (e.g., Breen, (2001), Hall and Verplaetse, (2000) and Morell, (2002). The interaction between learners and teachers has received an enormous amount of attention during the past 30 years from researchers in a wide range of disciplines.

Interactive lectures play an important role in improving comprehension and in enhancing communicative competence in the English language.

Teachers involved in the field of ESL or EFL have a range of instructional material available, namely speech events such as seminars and tutorials; but the lecture "remains the central instructional activity" (Flowerdew, 1994). In lectures teachers seem to invite students to interact and participate more than in previous times, what may be seen as an attempt to narrow distances and avoid formalisms.

Research into lecture comprehension is related to question of how of teaching and learning (Flowerdew, 1994), and therefore being of great help in applied linguistics. Both the lecturers and learners can benefit from how the listening comprehension process and different features of lectures work.

The literature on L2 lecture comprehension suggests that listeners continue to experience difficulties, even at advanced proficiency levels (Mulligan \& Krikpatrick, 2000; Thompson, 1994). But what are the causes of these difficulties? Flowerdew (1994) discusses a number of variables involved in lecturing to international audiences that have an impact on successful comprehension, ranging from delivery speed to some particular lexico-grammatical, interpersonal, disciplinary and culture-related features of lecture discourse.

Lecture discourse has been conventionally known to be of a monologue nature. Traditionally, a lecture has been considered an institutionalized extended holding of the floor in which one speaker imparts his view on a subject using a slightly impersonal style (Goffman, 1981, p. 165).

The use of conversational style lectures allows for interaction among lecturers and students. There are, of course, different degrees of interaction within lectures and distinct levels of asymmetrical power among participants. 
A common experience among new teachers is learning how to lecture. Lecturing is a skill, a strategy, and a practice. As a skill, lecturing is learned over time. For example, teachers learn how to select content to hold students' attention. Lecturing is a strategy that teachers use when they want to efficiently cover a great deal of content. In addition, it is a practice that has shared meanings, practical knowledge, and language.

According to Swanson and Torraco (1995), the lecture was established formally centuries ago as a teaching process that began with a literal reading of important passages from the text by the master, followed by the master's interpretation of the text. Students were expected to sit, listen and take notes.

However, giving a good lecture is an art, akin to a stage performance in which the lecturer is the protagonist and holds the audience's attention to the end. Some of the skills involved in giving a good lecture stem from the lecturer's personality, but others can undoubtedly be practiced and learnt.

The present study investigates the effects of discourse markers in lectures on written texts, i.e., whether the use of discourse markers in lectures has positive effect on producing more cohesive texts. Therefore, two topics were chosen for lectures, one using discourse markers and the other without discourse markers for two groups. After lecturing by the teacher, the students were asked to write whatever they understood from the lecture. The texts were compared to see which of these two groups produced more cohesive texts, i.e., used more cohesive devices in their compositions.

\section{BACKGROUND OF THE STUDY}

\section{A. The Genre of Lecture}

Students' comprehension of academic discourse has become an important focus of study especially due to the numbers of university students who are attending lectures held in English (Alcaraz Varó, 2000; Flowerdew, 1994; Flowerdew \& Peacock, 2001; Jordan, 1997). Many of these studies have attempted to determine what variables of the lecture discourse play a role in improving non-native speakers' understanding of the content. Among the variables are lecture schemata, speech modifications, use of visual aids, note-taking and interaction (Morell, 2000). To improve L2 students' comprehension, studies on lecture discourse recommend that lecturers use, for example, accurate representation of the macro-structure (Tauroza \& Allison, 1994; Olsen \& Huckin, 1990) and discourse markers (e.g., Thompson, 2003), an adequate speech rate (Griffiths, 1990), repetitions (Chiang \& Dunkel, 1992), and the possibility of negotiating meaning (Lynch, 1994; Morell, 2004).

Lectures have not only been studied to determine what will facilitate students' comprehension, but also to examine their role as events that can be beneficial for the linguistic and communicative competence of second and foreign language students. Wesch and Ready (1985) claimed that "gains in second language proficiency are best achieved in situations where the second language is used as a vehicle for communication about other subjects rather than itself." In other content lecture studies based in countries where English is not the official language (Griffiths, 1990; Morell, 2000), it has been found that in many cases interactive lectures will benefit EFL students not only in so far as their comprehension is concerned, but also in terms of improving their linguistic and communicative competence.

Furthermore, a number of recent studies on academic spoken discourse (Crawford Camiciottoli (2004) and Crawford Camiciottoli (2005); Fortanet, (2004); Hincks, (2005); Hood \& Forey, (2005); Miller, (2002); Morell, (2004); Recski, (2005); Webber, (2005)) have focused on the interpersonal features and, for the most part, suggest that the tenor, that is, the relationship between the speaker and listeners, plays an essential part in establishing a comfortable context that will encourage participation. In addition, other studies have revealed the importance of the interpersonal relations established within spoken academic situations that will increase the non-native speakers' willingness to communicate and in turn contribute to their successful acquisition of the second language (Kang, 2005). A considerable body of research has examined various aspects of lectures (e.g. Bligh, 1972). One strand of this research has investigated the structure of lectures and the ways in which different styles of lecture lead to different outcomes for the student. So Flowerdew and Miller (1995, 1997) have looked at the notion of cultures in lectures, Khuwaileh (1999) has examined the role of lexical chunks and body language, and Thompson (1994), amongst others, has looked at the discourse structure of lectures.

\section{B. Discourse Markers}

In linguistics, a discourse marker is a word or phrase that is relatively syntax-independent and does not change the meaning of the sentence, and has a somewhat empty meaning. Examples of discourse markers include the particles "oh", "well", "now", "then", "you know", and "I mean", and the connectives "so", "because", "and", "but", and "or".

Although discourse markers are usually considered to be textual units that guide readers or listeners in their comprehension of a written or spoken text, they also act as interpersonal features. According to Chaudron and Richards (1986), discourse markers can be grouped into macro-markers, which are higher-order markers signaling major transitions and emphasis in the lectures, and micro-markers, which are lower-order markers of segmentation and intersentential connections. The interpersonal features of discourse markers can be readily perceived in macro-markers that specify the lecturer's attitude (e.g., I believe, I think, I agree with), that elicit responses (e.g., what do you think about...?) and that accept responses (e.g., that's absolutely right).

Discourse markers are part of gathering of linguistic features enhancing and fostering successful lecture comprehension. Thus from the 70s onwards researchers into the lecture comprehension process whether in L1 or L2 
have pointed out the effectiveness of learning about discourse markers for the comprehension of connected discourse (Cook, 1975; Murphy and Candlin, 1979; Kintsch and Yarbrough, 1982; Chuadren and Richards, 1986).

Discourse markers have been largely studied by researchers and they are still focusing their interest. Researchers may agree on the underlying concept of discourse markers but they use different names to refer to that very same concept. Thus we find labels such as: cue phrases (Knott and Dale, 1994), discourse connectives (Redeker, 1990), discourse signaling devices (Polanyi and Scha, 1983), pragmatic connectives (Van Dijk et al. 1978; Stubs, 1983) among others.

There are different categories of discourse markers. Fraser (2004) states there are five separate and distinct categories that contribute primarily to DMs:

1. Coordinate Conjunctions: and, but, or, so, yet...

2. Subordinate Conjunctions: after, although, as, as far as, as if, as long as, if, immediately...

3. Adverbials: anyway, besides, consequently, furthermore, still, however, then...

4. Prepositional Phrases: above all, after all, as a consequence, in fact, in general.....

5. Prepositions: despite, in spite of, instead of, rather than....

Under the semantic point of view, Fraser (2004) proposes a marginal DMs classification as follows:

1. Contrastive Markers (CDMs): but, alternatively, although, conversely, despite (this/that), in spite of (this/that), in contrast to...

2. Elaborative Markers (EDMs): and, above all, also, besides, by the same token, equally, for example, in particular....

3. Implicative Markers (IDMs): so, after all, all things considered, as a conclusion, as a consequence, hence, accordingly, then, therefore...

4. Temporal Markers (TDMs): then, after, as soon as, before, eventually, finally, first, meantime, meanwhile.....

\section{Cohesive Devices}

As one of the four basic language skills, writing is more complex in that it tests a person's ability to use a language and the ability to express ideas. As a result, a person needs to write not only coherently but correctly, which requires much more time and skills. This is especially so when writing in a second/foreign language. Cohesion and coherence, two important textual elements (Halliday and Hasan, 1976; Halliday, 2000), have long been recognized as important features of "good" writing.

Print texts achieve coherence in two ways: through words and through context. Conventional advice focuses on the relationship between words, as we see in the advice offered by Daniel Kies (2003):

Coherence is product of many different factors, which combine to make every paragraph, every sentence, and every phrase contribute to the meaning of the whole piece. Coherence in writing is much more difficult to sustain than coherent speech simply because writers have no nonverbal clues to inform them if their message is clear or not. Therefore, writers must make their patterns of coherence much more explicit and much more carefully planned. Coherence itself is the product of two factors - paragraph unity and sentence cohesion. (n.p.)

Cohesion refers to the explicit linguistic devices that link the sentences in a text. These cohesive devices include reference, substitution, ellipsis, conjunction and lexical cohesion (Halliday \& Hasan, 1976), and since they are manifested at the surface level of a text, cohesion should be relatively straightforward to identify. Textual cohesion is a critical aspect of successful language processing and comprehension and is premised on building connections between ideas in text. As noted by both Silva (1993) and Ferris (1994), cohesion plays an important part in the lexical development of L2 writers, and it also serves as a means to distinguish differences between L1 and L2 writers.

One of the most important objectives of writing in an academic environment is to create texts that are coherent and cohesive in order to establish successful communication within an academic community. Thus, the analysis of the use of cohesive devices has been of great interest for researchers and language instructors involved in the study and teaching of academic writing (Connor, 1984; Hinkel, 2001; Nesi \& Basturkmen, 2006).

Several studies have compared the use of cohesive devices in the writing of native and non-native speakers of English (Connor, 1984; Francis, 1989; Hinkel, 2001; Scarcella, 1984). Most of these studies reported that non-native speakers' use of certain lexical cohesive devices was often rare or inappropriate. Hinkel (2001) reports that even the advanced non-native speaker writers in her study did not use a wide variety of cohesive ties to achieve a unified text.

Research on cohesion and coherence in writing has been flourishing since the publication of Cohesion in English (Halliday and Hasan, 1976). Halliday and Hasan propose that in any language, such grammatical and lexical devices as reference, ellipsis, substitution, conjunction and lexical cohesion create "texture'" the property of being a text. These devices form cohesive relations between sentences and elements in sentences, thus contributing to the coherence of the text.

\section{Methodology}

\section{A. Participants}

The participants in this study were 20 male advanced EFL learners, aged 25 to 40, chosen from one of the language institutes in Isfahan. The participants were divided into two groups of 10. All the participants took the placement test required for admission to study English in the institute. They studied Passage 2, $2^{\text {nd }}$ edition, in 30 sessions. 


\section{B. Materials}

The material in this study was the Passage book which was taught by the teacher (me) in 30 sessions. Also, one topic for lecture was chosen for the participants, which was related to one of the topics in their book.

\section{Procedures}

First, the 20 EFL learners were divided into two groups. Two texts for giving lectures were chosen related to "Science and Technology", as it was the title of unit 3 of Passage 2. In order to compare the participants' comprehension of the texts, discourse markers were used in the lecture of group 1 (G1) and in the other lecture for group 2 (G2) no discourse marker was used. As it was explained in the background of the study above, several studies have shown that using discourse markers in lectures facilitate comprehension. It has been tested several times for speaking. Therefore, the aim of this study was to investigate whether this effect is also seen on writing or not, i.e., whether the learners who listened to the lecture using discourse markers could produce more coherent texts and use more cohesive devices or not. Actually, the base for comparison between the writings of two groups was the use of cohesive devices. As for data analysis, cohesive devices used in each composition were identified and counted by the researchers. Then, frequency, mean and standard deviation of the cohesive devices in each category were computed using SPSS.

\section{Results}

\section{Assessment Results}

Altogether, 20 compositions were collected. The scores given to each composition by the researchers were sorted and the mean was determined as the final score for that piece. The results are presented in Table 1 below.

As shown in Table 1, the mean score of the 20 compositions was 20.6 (out of a maximum score of 25). Thus, the compositions scored 23 or above were considered the best, while those scored 16 or below the weakest. Since most of the scores fell into the range from 18 to 23 (mean score \pm SD), the students in this study could be considered similar in writing ability. (Marking criteria for assessing writing were similar to other studies: 21-25: Main ideas stated clearly and accurately; well organized and perfectly coherent; very effective choice of words; no errors; full control of complex structure. 16-20: Main ideas stated fairly and accurately; fairly well organized and generally coherent; effective choice of words; almost no errors; good control of structure. 11-15: Loosely organized but main ideas clear; logical but incomplete sequencing; adequate choice of words but some misuse of words; many errors. 6-10: Main ideas not clear or accurate; ideas disconnected; lacks logical sequencing; limited range and confused use of words; a lot of errors; poor control of structure. 0-5: Main ideas not at all clear or accurate; no organization; incoherent; very limited range and very poor knowledge of words; full of errors; no control of structure.)

TABLE I.

DESCRIPTIVE STATISTICS

\begin{tabular}{|c|c|c|c|c|c|c|}
\hline$\overline{\text { Mean }}$ & Standard Deviation & Standard Error & Minimum & Maximum & Range & Median \\
\hline 20.6 & 2.36 & 0.33 & 14 & 24 & 10 & 20 \\
\hline
\end{tabular}

Cohesive devices

Applying Halliday and Hasans (1976) cohesive framework as the basis for data analysis, the number of cohesive devices used in each composition was counted, followed by the determination of the frequency, mean and standard deviation of the cohesive devices in each category. However, in the actual analysis, two types of cohesion, substitution and ellipsis, were not included because "they are more characteristically found in dialogues" (Halliday, 2000, p. 337) and they are seldom used in formal writing.

Table 2 and 3 below present the number and percentage of the different subcategories of grammatical and lexical cohesive devices identified in the compositions of two groups. They show that the students in the present study employed a variety of cohesive devices with some types of devices used more frequently than others.

Based on the percentage of each cohesive tie, it is evident that the lexical devices had the highest percentage for both groups $(\mathrm{G} 1=60.3 \%$; G2 $=50.7 \%)$, followed by the reference devices $(\mathrm{G} 1=24.7 \%$; $\mathrm{G} 2=20.3 \%)$ and the conjunction devices $(\mathrm{G} 1=15 \% ; \mathrm{G} 2=29 \%)$.

TABLE 2.

DESCRIPTIVE STATISTICS OF COHESIVE DEVICES FOR G1

\begin{tabular}{|l|l|l|l|l|}
\hline Type of cohesive devices & Reference devices & Conjunction devices & lexical devices & Total \\
\hline Frequency & 1546 & 725 & 2723 & 4994 \\
\hline Mean & 20.8 & 11.7 & 64.2 & 96.7 \\
\hline Standard deviation & 12.3 & 4.8 & 11.6 & 27.15 \\
\hline Standard error & 1.85 & 0.87 & 1.92 & 4.2 \\
\hline Range & 75 & 32 & 62 & 123 \\
\hline Percentage based on total & $24.7 \%$ & $15 \%$ & $60.3 \%$ & $100 \%$ \\
\hline
\end{tabular}


TABLE 3.

DESCRIPTIVE STATISTICS OF COHESIVE DEVICES FOR G2

\begin{tabular}{|l|l|l|l|l|}
\hline Type of cohesive devices & Reference devices & Conjunction devices & lexical devices & Total \\
\hline Frequency & 1423 & 698 & 2658 & 4779 \\
\hline Mean & 28.46 & 13.96 & 53.16 & 95.58 \\
\hline Standard deviation & 11.49 & 5.41 & 11.75 & 23.12 \\
\hline Standard error & 1.63 & 0.77 & 1.66 & 3.27 \\
\hline Range & 63 & 30 & 56 & 112 \\
\hline Percentage based on total & $20.3 \%$ & $29 \%$ & $50.7 \%$ & $100 \%$ \\
\hline
\end{tabular}

\section{DisCUSSION AND CONCLUSION}

The total number of cohesive devices used in the compositions of both groups were counted and compared. The findings reveal that the participants in G1 used more cohesive devices in their writings compared to G2, i.e., those who listened to the lecture containing discourse markers produced more coherent texts. In this study, the cohesive devices were divided into three categories: Lexical devices, Reference devices and Conjunction devices. The frequency of use of cohesive devices indicate that the participants in each group used lexical devices more than reference devices and conjunction devices were used less than the others. However, the frequency of use of each of these three types of cohesive devices for G1 was more than G2.

Being the main carrier of message and the means of expression, lexical items are the principal components of any composition. That may contribute to the fact that lexical devices are the most extensively used categories of cohesion in students' writings. However, because lexicon involves both meaning and usage, it becomes a much more complicated and difficult task for foreign learners of English. Lexical devices include repetition, antonyms, synonyms, superordinate and collocations. The greatest problem the students had in using lexical devices was the wrong use of collocations. The wrong use of collocations involved phrases, verbs, nouns and prepositions.

Although reference devices were the second most extensively used categories of cohesion in the students' writing, the students appeared not to be at ease with their use. The problems with the use of reference devices were mainly of three types: the shifted use of pronouns; omission or misuse of the definite article; and underuse of comparatives and overuse of the phrase 'more and more'. The students in this study tended to shift pronouns within or between clauses such as from the first person to the second or from the singular form to the plural. As a result, the referents and the referring items were made inconsistent, which often times confused the reader and even caused problems in comprehension.

With regard to the use of conjunctions, it seems that the students were capable of using a variety of devices to bridge the previous sentence(s) and the following one(s) to make their writing clearer and more logical. However, only those commonly used items as "and", "but", "or" and "so" were the students' favorites, whereas the items learned later such as "furthermore", "on the contrary", "moreover", "in addition", "on the whole", and "nevertheless" seldom occurred in their writing.

Although lexical cohesion was the most extensively used category of cohesive devices, it appeared to be an area that needs improvement for students even in advanced levels. The students demonstrated a limited choice in the use of lexical items and the great majority of the lexical devices were repetitiously used. The rare use of synonyms, antonyms, superordinates, and general words indicates that much needs to be done in the teaching of vocabulary in Iran. As a consequence, much needs to be done in the teaching of writing to enhance the students' awareness of the importance and use of cohesive devices in their writing. First of all, as marking criteria set the standard for judging a piece of writing, teachers and learners should be familiarized with the marking criteria for different writing tests. It is the teachers' responsibility to first comprehend and then explain the marking and assessing criteria in the class, and thereby enhance students' awareness of what contributes to the quality of writing (Densteadt, 1996). As a result, the students will know what to emphasize when writing in English.

In addition, focused activities should be developed in combination with explicit instruction. The students can be required to write a paragraph for 3-5 min, using different cohesive devices. Following that, peer review could be used to analyze the cohesive devices used in each other's writing and comment on the effects of using those cohesive devices. After each task is finished, it is necessary for the writing teacher to choose a sample composition for critique, stressing the importance of using cohesive devices effectively and appropriately and reminding the students to avoid overusing or underusing cohesive devices.

Since the acquisition of English vocabulary by EFL learners is a thorny task because there are subtle devices in each word as far as meaning and use are concerned, this kind of teaching may not be effective on the learning of lexical devices, which concern far more aspects of language such as semantics and pragmatics. In order to raise the students' syntactic and semantic awareness, they should be encouraged to read as extensively as possible. By doing this, they will not only extend their vocabulary but also better understand the use and meaning of words in different contexts. Apart from reading, it is necessary to train the students to paraphrase words or phrases by means of synonyms, antonyms, hyponyms or examples through exercises. Thus, they would not only recall as many words as possible but will be able to create more vivid and effective compositions through the use of lexical devices. 
A final word is that the findings of this study can possibly be applicable to other EFL contexts outside Iran as well. However, methods of improving EFL/ESL learners' writing and the effects of different teaching methods need further examination in other actual contexts.

\section{REFERENCES}

[1] Alcaraz Varó, E. (2000). El inglés profesional y academic. Alianza Editorial, Madrid.

[2] Basturkmen, H. (1999). Discourse in MBA seminars: Towards a description for pedagogical purposes. English for Specific Purposes, 18, 1, 63-80.

[3] Bligh, D. A. (1972). What's the Use of Lectures? Penguin: Harmondsworth.

[4] Breen, M. (2001). Overt participation and covert participation in the language classroom. In: M. Breen, Editor, Learner contributions to language learning: new directions in research. Pearson, Harlow, 112-140.

[5] Chaudron, C. and Richards, J. C. (1986). The effect of discourse markers on the comprehension of lectures, Applied Linguistics, 7, 2, 113-127.

[6] Chiang, C.S. and Dunkel, P. (1992). The effect of speech modification, prior knowledge and listening proficiency on EFL lecture learning, TESOL Quarterly, 26, 2, 345-374.

[7] Connor, U. (1984). A study of cohesion and coherence in English as a second language student's writing. Papers in Linguistics, 17, 301-316.

[8] Crawford Camiciottoli, B., (2004). Interactive discourse structuring in L2 guest lectures: Some insights from a comparative corpus-based study. Journal of English for Academic Purposes 3 1, pp. 39-54.

[9] Crawford Camiciottoli, B. (2005). Adjusting a business lecture for an international audience: A case study. English for Specific Purposes, 24, 183-199.

[10] Cook, J. R. S. (1975). A communicative approach to the analysis of extended monologue discourse and its relevance to the development of teaching materials for ESP. Unpublished M. Litt. Thesis. Edinburg: University of Edinburg.

[11] Densteadt, J. (1996). Balancing the teaching and assessment of writing. TESOL Quarterly, 6, 35-36.

[12] Ferris, D. R. (1994). Lexical and syntactic features of ESL writing by students at different levels of L2 proficiency. TESOL Quarterly, 28, 414-420.

[13] Flowerdew, J. (1994). Academic listening: Research perspectives. Cambridge University Press: Cambridge.

[14] Flowerdew, J. and Miller, L. (1995). On the notion of culture in L2 lectures. TESOL Quarterly, 29, 2, $345-373$.

[15] Flowerdew, J. and Miller, L. (1997). The teaching of academic listening: comprehension and the question of authenticity. English for Specific Purposes, 16, 1, 27-46.

[16] Flowerdew, J. and Peacock, M. (2001) In: J. Flowerdew and M. Peacock, Editors, Research perspectives on English for academic purposes, Cambridge University Press, Cambridge.

[17] Fortanet, I. (2004). The use of 'we' in university lectures. Reference and function. English for Specific Purposes, 23 , 45-66.

[18] Francis, G. (1989). Aspects of nominal-group lexical cohesion. Interface: Journal of Applied Linguistics, 4, 27-53.

[19] Fraser, B. (2004). An account of discourse markers. In Garcés, P., R. Gómez, L. Fernández, \& M. Padilla. (Eds.). Current trends in intercultural, cognitive and social pragmatics. Sevilla: Universidad de Sevilla: 13-34.

[20] Gass, S. (1997). Input, interaction, and the second language learner, Erlbaum, Mahwah, NJ.

[21] Gass, S. and Madden, C. (1985). Input in second language acquisition. Newbury House Publishers, Cambridge, MA.

[22] Gass, S. and Varonis, E. (1994). Input, interaction, and second language production. Studies in Second Language Acquisition, $16,283-302$.

[23] Goffman, E. (1981). Forms of Talk. Basil Blackwell, Oxford.

[24] Green, C. F., Christopher, E. R. and Jacquelyn, L. (2000). The incidence and effects on coherence of marked themes in interlanguage texts: a corpus-based enquiry. English for Specific Purposes, 19, 99-113.

[25] Griffiths, R. (1990). Speech rate and NNS comprehension: A preliminary study in time-benefit analysis, Language Learning, 40 (3), 311-336.

[26] Halliday, M. A. K. (2000). Introduction to Functional Grammar. Foreign Language Teaching and Research Press. Beijing.

[27] Halliday, M. A. K. and Hasan, R. (1976). Cohesion in English. Longman, London.

[28] Hall, J. K. and Verplaetse, L. S. (2000). Second and foreign language learning through classroom interaction. Lawrence Erlbaum. Mahwah, NJ.

[29] Hincks, R. (2005). Measures and perceptions of liveliness in student oral presentation speech: Proposal for an automatic feedback mechanism, System, 33, 575-591.

[30] Hinkel, E. (2001). Matters of cohesion in L2 academic texts. Applied Language Learning, 12, 111-132.

[31] Hood, S. and Forey, G. (2005). Introducing a conference paper: Getting interpersonal with your audience. Journal of English for Academic Purposes, 4 (4), 291-306.

[32] Jafarpur, A. (1991). Cohesiveness as a basis for evaluating compositions. System, 19, 459-465.

[33] Johns, A. M. (1980). Cohesion in written business discourse: some contrasts. The ESP Journal, 1, 36-44.

[34] Johnson, D. P. (1992). Cohesion and coherence in compositions in Malay and English. RELC Journal, 23, 1-17.

[35] Kang, S. (2005). Dynamic emergence of situational willingness to communicate in a second language. System, 33, $277-292$.

[36] Khuwaileh, A. A. (1999). The role of chunks, phrases and body language in understanding coordinated academic lectures. System, 27 (2), 249-260.

[37] Kies, D. (2003). Coherence in writing. Retrieved from http://papyr.com/hypertextbooks/engl 101/coherent.htm>.

[38] Kintsch, W. and Yarbrough, J. C. (1982). Role of rhetorical structure in text comprehension. Journal of Educational Psychology, 74(6), 828-834.

[39] Knott, A. and Dale, R. (1994). Using linguistic phenomena to motivate a set of coherence relations. Discourse Processes, 18, 1, $35-62$.

[40] Long, M. (1981). Questions in foreigner talk discourse. Language Learning, 3,11, 35-158. 
[41] Lynch, T. (1994). Training lectures for international audiences. In: J. Flowerdew, Editor, Academic listening: Research perspectives, Cambridge University Press, Cambridge, 269-289.

[42] Miller, L. (2002). Towards a model for lecturing in a second language. Journal of English for Academic Purposes, 1, $145-162$.

[43] Morell, T. (2000). EFL content lectures: A discourse analysis of an interactive and a non-interactive style. Working papers 7. Alicante, Spain: Departamento de Filología Inglesa, Universidad de Alicante.

[44] Morell, T. (2002). La interacción en la clase magistral: Rasgos lingüísticos del discurso interactivo en inglés. Universidad de Alicante, unpublished doctoral thesis.

[45] Morell, T. (2004). Interactive lecture discourse for university EFL students. English for Specific Purposes, 23, 3, 325 -338.

[46] Mulligan, D. and Kirkpatrick, A. (2000). How much do they understand? Lectures, students and comprehension. Higher Education Research and Development 19, 2, 311-335.

[47] Murphy, D. F., and Candlin, C. N. (1979). Engineering lecture discourse and listening comprehension. Practical Papers in English Language Education, 2, 1-79.

[48] Nesi, H. and Basturkmen, H. (2006). Lexical bundles and discourse signaling in academic lectures. International Journal of Corpus Linguistics, 11, 147-168.

[49] Northcott, J. (2001). Towards an ethnography of the MBA classroom: A consideration of the role of interactive lecturing styles within the context of one MBA program. English for Specific Purposes, 20, 15-37.

[50] Olsen, L. A. and Huckin, T. N. (1990). Point-driven understanding in engineering lecture comprehension. English for Specific Purposes, 9, 33-47.

[51] Pica, T., Young, R. and Doughty, C. (1987). The impact of interaction on comprehension. TESOL Quarterly, 21, 4, 737-758.

[52] Polanyi, L. and Scha, R. (1983). The syntax of discourse. Text 3, 261-270.

[53] Recski, L. (2005). Interpersonal engagement in academic spoken discourse: A functional account of dissertation defenses. English for Specific Purposes, 24, 1, 5-23.

[54] Redeker, G. (1990). Ideational and pragmatic markers of discourse structure. Journal of Pragmatics, 14, 3, 367-381.

[55] Scarcella, R. C. (1984). Cohesion in the writing development of native and nonnative English speakers. Unpublished doctoral dissertation, University of Southern California, Los Angeles, CA.

[56] Silva, T. (1993). Toward an understanding of the distinct nature of L2 writing: The ESL research and its implications. TESOL Quarterly, 27, 657-675.

[57] Swanson, R. A. and Torraco, R. J. (1995). The history of technical training. In: The ASTD Technical and Skills Training Handbook. Kelly L (ed). McGraw Hill: New York.

[58] Stubbs, M. (1983). Discourse analysis. Chicago, IL: The University Chicago Press.

[59] Tauroza, S. and Allison, D. (1994). Expectation driven understanding in information systems lecture comprehension. In: J. Flowerdew, Editor, Academic listening: Research perspectives, Cambridge University Press, Cambridge, 35-54.

[60] Thompson, S. (1994). Frameworks and contexts: a genre-based approach to analyzing lecture introductions. English for Specific Purposes, 13, 171-186.

[61] Webber, P. (2005). Interactive features in medical conference monologue, English for Specific Purposes, 24, $157-181$.

[62] Wesch, M. and Ready, D. (1985). Foreigner talk in the university classroom. In: S. Gass and J. Madden, Editors, Input in second language acquisition, Newbury House, Rowley, MA, 89-144.

[63] Yvette, F. and Yip, L. (1992). A comparison of Internet conjunctive cohesion in the English essay writing of Cantonese speakers and native speakers of English. RELC Journal, 23, 15-28.

[64] Zhang, M. (2000). Cohesive features in exploratory writing of undergraduates in two Chinese universities. RELC Journal, 31 , 61-93.

Afsaneh Rahimi Tehrani (1985, Isfahan, Iran) is currently an MA student at the university of Isfahan. Her area of interest is language learning and young EFL learners.

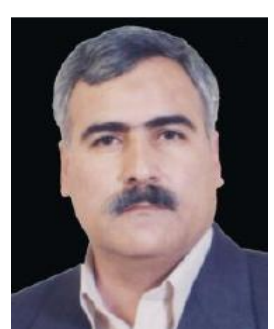

Hossein Vahid Dastjerdi teaches in the English Language Department at the University of Isfahan, Iran. He is associate professor of applied linguistics and has taught courses of variegated character, including translation courses, for years. He has been a fellow of the English Centers at the universities of Isfahan and Shiraz where he has investigated into issues related to materials preparation for GE. and ESP. courses. He is the author of a number of books in this respect. He has also published a good number of articles on discourse, testing and translation in local and international journals.

Dr. Vahid's current research interests include testing, materials development, translation, the metaphoricity of language, discourse analysis, pragmatics and critical discourse analysis. He is presently involved in a number of projects concerning translation studies as well as figurative language use. 